\title{
Multimodal treatment of Kasabach-Merritt syndrome arising from tufted angioma: A case report
}

\author{
RUN-SONG JIANG and ZHENG-YAN ZHAO
}

\begin{abstract}
Department of Reconstructive Plastic Surgery, The Children's Hospital of Zhejiang University School of Medicine, Hangzhou, Zhejiang 310003, P.R. China
\end{abstract}

Received March 5, 2015; Accepted April 5, 2016

DOI: $10.3892 / 01.2017 .6064$

\begin{abstract}
Kasabach-Merritt syndrome (KMS) is a rare type of vascular tumor associated with a severely decreased platelet count. No standard guidelines for the treatment of the disease have been established so far. In the present study, a 1-year-old pediatric patient with KMS arising from tufted angioma was successfully and variously treated with steroids, vincristine, surgery and propranolol for 18 months. Systemic steroids stabilized the platelet count stable, while vincristine reduced the size of the tumor. Due to unpredictable response, the patient was operated. Combination of vincristine and propranolol was introduced post-surgery to improve the severely low platelet count of the patient. Following multimodal therapy for 18 months, there has been no evidence of recurrence or metastasis during 2 years of follow-up. Currently, the patient is alive and well. The management of KMS presents a challenge, and well-designed studies are required to clearly determine the benefits and risks of multidisciplinary treatment.
\end{abstract}

\section{Introduction}

Kasabach-Merritt syndrome (KMS) is a rare, aggressive type of vascular tumor associated with thrombocytopenia and consumptive coagulopathy. KMS was first reported by Kasabach and Merritt in 1940, in a boy presenting with enlarging hemangioma with thrombocytopenia on the left thigh (1). KMS has been associated with Kaposiform hemangioendothelioma or tufted angioma, but not with the more common infantile hemangioma (2). Le Nouail et al (3) estimated the mortality rate to be between $13 \%$ and $24 \%$, depending on the series. Numerous regimens have been employed for the management of KMS, without, however, a consistent response, since patients exhibit a variable and unpredictable response to traditional

Correspondence to: Professor Zheng-Yan Zhao, Department of Reconstructive Plastic Surgery, The Children's Hospital of Zhejiang University School of Medicine, 57 Zhugan Lane, Yanan Road, Hangzhou, Zhejiang 310003, P.R. China

E-mail: Jiangrs97@gmail.com

Key words: Kasabach-Merritt syndrome, tufted angioma pharmacological agents, including steroids, vincristine and interferon (IFN). Recently, excellent response rates and prompt results have been achieved by combining antiplatelet therapy with vincristine, without the use of steroids. Sirolimus, which is directed against the phosphatidylinositol-4,5-bisphosphate 3-kinase/AKT/mechanistic target of rapamycin downstream signalling pathway and is involved in lymphangiogenesis, has also shown promising results (4). No standard guidelines for the treatment of the disease have been established so far. In certain cases, multimodal therapy is necessary. The main therapeutic options include systemic corticosteroid therapy, IFN $\alpha 2 \mathrm{a}$ or $2 \mathrm{~b}$, vincristine and platelet aggregation inhibitors, possibly in combination with acetylsalicylic acid or ticlopidine (3).

\section{Case report}

A 1-year-old pediatric patient was admitted to the Department of Reconstructive Plastic Surgery, The Children's Hospital of Zhejiang University School of Medicine (Hangzhou, China) for the management of an erythematous and swollen process on his right shoulder in July 2010. The lesion was a reddish-violaceous plaque measuring $8 \times 6 \mathrm{~cm}$, irregularly shaped, poorly demarcated and showed signs of swelling and inflammation (Fig. 1). The lesion first appeared as a small skin lesion the size of a peanut. Six months later, it had increased in size and become slightly tender and warm upon palpation. Treatment with antibiotics (cefmenoxime, $80 \mathrm{mg} / \mathrm{kg}$ ) for 1 month failed. Laboratory tests revealed the following: Platelet count, $77 \times 10^{9} / 1$ (normal range, $100-400 \times 10^{9}$ cells/1); hemoglobin, $115 \mathrm{~g} / 1$ (normal range,110-140 g/l); leukocyte count, $9.49 \times 10^{9}$ cells/1 (normal range, $4.00-12.00 \times 10^{9}$ cells $/ 1$ ); D-dimer, $302 \mu \mathrm{g} / 1$ (normal range, <500 $\mu \mathrm{g} / 1$ ). Doppler ultrasound (IU Elite; Philips Healthcare, Amsterdam, The Netherlands) showed a fluid collection in the subcutaneous tissue and muscle plane of the patient's right shoulder and computed tomography scan (Somatom Emotion 16; Siemens AG, Munich, Germany) demonstrated a vascular tumor extending to the right clavicle. Based on thrombocytopenia, consumptive coagulopathy and purpura associated with a huge vascular tumor, the patient was diagnosed as KMS. Informed consent was obtained from the patient's parents prior to treatment and the present study was approved by the Ethical Committee of Zhejiang University. 
Treatment with methylprednisolone was administered intravenously at a dose of $10 \mathrm{mg} / \mathrm{kg} / \mathrm{day}$ for 3 days and tapered off over 2 weeks. Subsequently, 5 intralesional injections of compound betamethasone (diprospan) were administered at a dose of $1 \mathrm{ml}(7 \mathrm{mg})$ twice a week, which was equivalent to $10 \mathrm{mg} / \mathrm{kg} / \mathrm{day}$ methylprednisolone. Despite the stabilization of the platelet count following treatment, the lesion continued to enlarge. A weekly intravenous injection of $1.5 \mathrm{mg} / \mathrm{m}^{2}$ vincristine was therefore added upon termination of the treatment. Following 6 injections of vincristine at a dose $0.68 \mathrm{mg}$ (according his body surface area), the platelet count was found to have increased to $264 \times 10^{9} / 1$, and the mass in the right shoulder to have shrank. The patient was discharged and received weekly blood tests to ensure that the platelet count was stable.

A month later, the patient was readmitted to the Department of Reconstructive Plastic Surgery, The Children's Hospital of Zhejiang University School of Medicine, presenting with a cough and a decreased platelet count of $78 \times 10^{9} / 1$. A posterior-anterior view of the chest was obtained using X-rays, which demonstrated pneumonia. Several antibiotics were altered for dealing with pneumonia and the weekly injection of vincristine was reinitiated for 2 weeks. No further improvement in the platelet count was observed. Laboratory test results showed the following: Platelet count, $86 \times 10^{9}$ cells $/ 1$ (normal range, 100-400×10 ${ }^{9}$ cells/1); white blood cell count, $5.96 \times 10^{9}$ cells $/ 1$ (normal range, 4.00-12.00 $\times 10^{9}$ cells $/ 1$ ); hemoglobin, $97 \mathrm{~g} / 1$ (normal range, 110-140 g/l); C-reactive protein, $<1 \mathrm{mg} / 1$ (normal range, $<1 \mathrm{mg} / \mathrm{l}$ ); D-dimer, $853 \mu \mathrm{g} / \mathrm{l}$ (normal range, $<500 \mu \mathrm{g} / \mathrm{l}$ ); prothrombin time, $11.6 \mathrm{sec}$ (normal range, 9.0-14.0 sec); activated partial thromboplastin time, $23.0 \mathrm{sec}$ (normal range, 23.0-28.0 sec); thrombin time, $18.8 \mathrm{sec}$ (normal range, 15.0-22.0 sec). An emergency surgery was scheduled. Intraoperatively, completely resecting the tumor and stopping the bleeding around the right clavicle was challenging. In the end, partial resection $(>90 \%)$ was performed and the wound was repaired by skin grafting. The patient was intraoperatively supplied with 3 units platelets $\left(60 \times 10^{9}\right.$ cells), 1 packed unit red blood cells (20 g hemoglobin) and $200 \mathrm{ml}$ plasma transfusions. On day 3 following surgery, the platelet count was $170 \times 10^{9}$ cells $/ 1$, and on day 10 it was $233 \times 10^{9}$ cells $/ 1$. The surgical specimen was fixed with $10 \%$ neutral formaldehyde (Shanghai Ling Feng Chemical Reagent Co., Ltd., Changshu, China) for $>24 \mathrm{~h}$ and paraffin embedded. The tissue slices (thickness, $4 \mu \mathrm{m}$ ) were stained with hematoxylin and eosin. Histopathology of the KMS revealed tufted angioma (TA). A tumor-like distribution of visible clustered capillary plexus in the dermis and subcutaneous tissue was observed. Low-magnification microscopy (DMLB2; Leica Microsystems GmbH, Wetzlar, Germany) showed a cannon-like appearance of the lesion (Fig. 2). No atypia was identified. Immunohistochemical staining revealed the following: Cluster of differentiation (CD) $31^{+}$(mouse; 1:100 dilution; GA610; DakoCytomation, Glostrup, Denmark), CD34+ (mouse; 1:100 dilution; IR632; DakoCytomation), smooth muscle actin ${ }^{+}$(mouse; 1:100 dilution; IR611; DakoCytomation), vascular endothelial growth factor $^{+}$(mouse; 1:100 dilution; M7273; DakoCytomation), vimentin $^{+}$(mouse; 1:100 dilution; IR630; DakoCytomation) and glucose transporter $1^{-}$(polyclonal rabbit; 1:250 dilution; ab652; Abcam, Cambridge, MA, USA). Upon changing the dressing, the wound was found to be clear and fresh. Two weeks later, however, wound dehiscence and skin graft necrosis were reported, while the platelet count was $187 \times 10^{9} / 1$, white blood cell count $7.33 \times 10^{9} / 1$ and C-reactive protein $<1 \mathrm{mg} / \mathrm{l}$. Unluckily, a decrease in the platelet count $\left(79 \times 10^{9} / 1\right)$ was again recorded 3 weeks after the surgery, so vincristine injections were repeated postoperatively. Following 4 injections over 1 month, the patient was discharged with a platelet count of $166 \times 10^{9} / 1$ and a healing wound.

Half a year later, the patient was readmitted to the Department of Reconstructive Plastic Surgery, The Children's Hospital of Zhejiang University School of Medicine presenting with a severely low platelet count of $36 \times 10^{9} / 1$. During preparation for platelet transfusion, a $63.08 \%$ positivity for platelet antibodies was detected (normal value, $<30 \%$ ). Platelet transfusion was delayed and propranolol was introduced to the parents. Due to refractoriness to previous treatments, the parents agreed to oral administration of propranolol for the treatment of KMS. First, the dose of propranolol was increased from $6 \mathrm{mg} /$ day to $24 \mathrm{mg} /$ day (split into 3 equal doses) for three days. The dose was maintained at $24 \mathrm{mg} /$ day in 3 equal doses $(2 \mathrm{mg} / \mathrm{kg} /$ day $)$ for 3 weeks until the platelet count increased to $134 \times 10^{9} / 1$. During that period, a bone marrow puncture was made to confirm the origin of platelet was normal. Following discharge from the hospital, oral propranolol at the dose of $30 \mathrm{mg} /$ day in 3 equal doses was administered for 5 months and subsequently tapered off. Meanwhile, vincristine was administered intravenously once a month, which resulted in a continued response for 5 months.

At the time of writing the present study, the patient was healthy without evidence of relapse for 2 years.

\section{Discussion}

KMS is a rare, aggressive type of vascular tumor that has been associated with thrombocytopenia and consumptive coagulopathy, which can result in a high risk of bleeding (5). KMS was first noted by Kasabach and Merritt in 1940 (1). Enjolras et al (2) suggested that KMS was caused by either hemangioendothelioma (KHE), TA or a combination of the two. KHE and TA probably belong to the same neoplastic spectrum and histological continuum (6).

The histopathology of the present case revealed that KMS was associated with TA, which is an infrequently observed benign vascular tumor that was first described by Nakagawa in 1949 under the name angioblastoma (7). The term TA was introduced by Wilson-Jones and Orkin in 1976, based on the characteristic histology of the lesion (8). TA is a solitary tumor or infiltrated plaque believed to have more of an inflammatory appearance than a vascular abnormality (5). The lesion has been described as small, cannonball-like, circumscribed angiomatous tufts and nodules in the dermis and subcutaneous tissue with characteristic lymphangioma-like vessels (9).

The pathogenesis of KMS remains unknown. Platelet trapping by an abnormally proliferating endothelium within the hemangioma may lead to the platelet activation, followed by secondary activation of coagulation cascades, eventually resulting in the consumption of various clotting factors $(3,10)$. Immunohistochemical analysis, using monoclonal antibodies 
Table I. Clinical profile of patients with tufted angioma with Kasabach-Merritt syndrome arising from tufted angioma.

\begin{tabular}{|c|c|c|c|c|c|c|c|c|c|}
\hline Author, year & Age & Gender & Site & Treatment & Outcome & Follow-up & $\begin{array}{l}\text { Year of } \\
\text { treatment }\end{array}$ & Country & Ref. \\
\hline $\begin{array}{l}\text { Ferrandiz-Pulido } \\
\text { et al, } 2010\end{array}$ & $1 \mathrm{~m}$ & Female & Chin & $\begin{array}{l}\text { Predinisone } \\
+ \text { aspirin + VCR } \\
+ \text { VAC combination } \\
+ \text { IFN } \alpha-2 \mathrm{a} \\
+ \text { Megadose } \\
\text { methylprednisolone }\end{array}$ & $\begin{array}{l}\text { Partial } \\
\text { response }\end{array}$ & $5 \mathrm{y}$ & 2005 & Spain & (5) \\
\hline Kim et al, 2010 & $2 \mathrm{~m}$ & Male & $\begin{array}{l}\text { Left } \\
\text { pubis }\end{array}$ & $\begin{array}{l}\text { Systemic } \\
\text { costicosteroid } \\
(\mathrm{DXM}+ \\
\text { predinisone) }\end{array}$ & $\begin{array}{l}\text { Complete } \\
\text { response }\end{array}$ & $1 \mathrm{y}$ & 2008 & Korea & (11) \\
\hline $\begin{array}{l}\text { Rodriguez et al, } \\
2009\end{array}$ & $6 \mathrm{w}$ & Female & $\begin{array}{l}\text { Left } \\
\text { elbow }\end{array}$ & $\begin{array}{l}\text { High-dose } \\
\text { methylprednisolone } \\
(30 \mathrm{mg} / \mathrm{kg} / \text { day }) \\
+\mathrm{VCR}\end{array}$ & $\begin{array}{l}\text { Near- } \\
\text { complete } \\
\text { response }\end{array}$ & $4 y$ & 2002 & USA & (16) \\
\hline Wang et al, 2014 & $2 \mathrm{~m}$ & Male & $\begin{array}{l}\text { Left } \\
\text { knee }\end{array}$ & $\begin{array}{l}\text { Predinisolone } \\
+ \text { propranolol } \\
+ \text { VCR } \\
+ \text { surgery }\end{array}$ & $\begin{array}{l}\text { Complete } \\
\text { response }\end{array}$ & $3 y$ & 2010 & China & (17) \\
\hline Chiu et al, 2012 & $2 \mathrm{~d}$ & Female & $\begin{array}{l}\text { Right } \\
\text { thigh }\end{array}$ & $\begin{array}{l}\text { Propranolol } \\
(3 \mathrm{mg} / \mathrm{kg} / \text { day })\end{array}$ & $\begin{array}{l}\text { Complete } \\
\text { response }\end{array}$ & $6 \mathrm{~m}$ & 2011 & USA & (18) \\
\hline Choi et al, 2013 & $15 \mathrm{~d}$ & Male & $\begin{array}{l}\text { Left } \\
\text { cheek }\end{array}$ & $\begin{array}{l}\text { IFN } \alpha \text {-2b } \\
+ \text { predinisolone } \\
+ \text { propranolol } \\
+ \text { VCR } \\
+ \text { VAC } \\
\text { combination }\end{array}$ & No response & $6 \mathrm{~m}$ & 2011 & Korea & (19) \\
\hline
\end{tabular}

w, week; m, month; d, day; y, year; VCR, vincristine; VAC, vincristine, actinomycin D and cyclophosphamide; IFN, interferon; DXM, dextromethorphan.

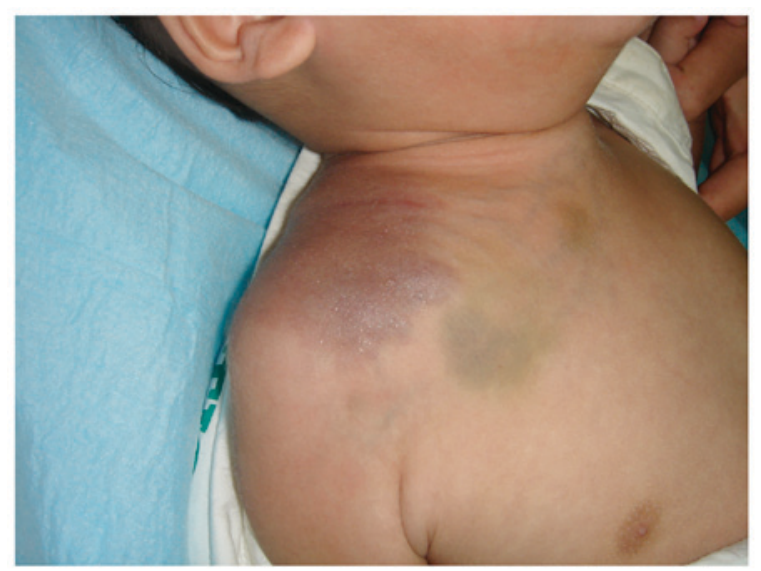

Figure 1. Preoperative photograph of the mass on the patient's shoulder.

against platelet marker CD61, and isotope analysis, using ${ }^{111}$ indium- and ${ }^{51} \mathrm{Cr}$-labeled platelets, have supported the importance of platelet trapping for the development of KMS (10). In addition, excessive blood flow and sheer stress, secondary to arteriovenous shunts within the tumors, could lead to further platelet activation (11).

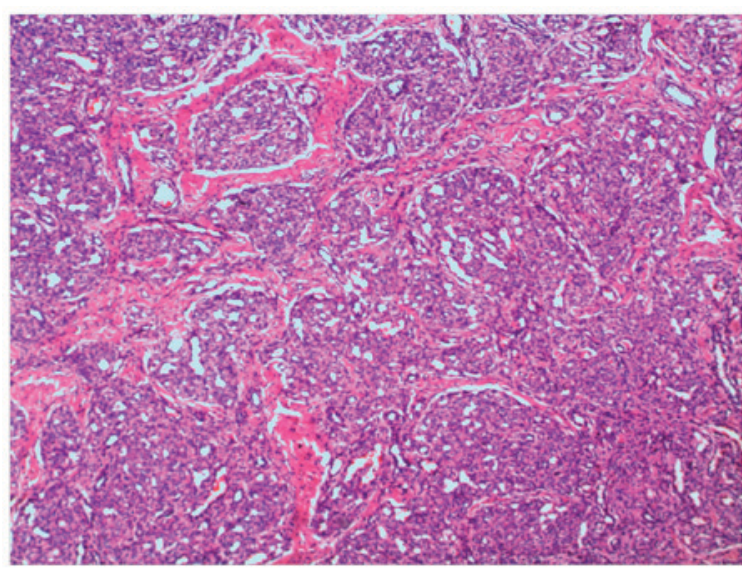

Figure 2. Cannonball-like distribution of small discrete vascular tufts fissured capillary and interstitial fibrosis (hematoxylin and eosin stain; magnification, $\mathrm{x} 40$ ).

The management of KMS is challenging due to its rarity and the lack of well-established systematic treatment strategies (11). Numerous therapeutic modalities have been employed for KMS, with no clear evidence that any type of treatment 
is superior over others. It has been suggested that multidisciplinary treatment is required for KMS (5). Several treatment regimens for KMS have been reported, including topical or systemic corticosteroid, IFN, chemotherapy, radiation, laser, propranolol, sirolimus and surgery (5,11-19; Table I).

In the present study, multimodal treatment with steroids, vincristine, surgery and propranolol was selected. An intralesional injection of compound betamethasone (diprospan) was administered at a dose of $1 \mathrm{ml}(7 \mathrm{mg})$ twice a week, equivalent to $10 \mathrm{mg} / \mathrm{kg} /$ day of methylprednisolone. As a megadose of a normal intralesional injection, compound betamethasone (diprospan) provided fast-acting and slow-acting treatment to ensure the drug concentration in the lesion was stable.

The reported adverse effects of steroid treatment include hypertension, cushingoid appearance and opportunistic infections (10). Vincristine is considered to be an effective treatment option for TA/KHE; it has been associated with a low incidence of side-effects and should, therefore, be used as first-line treatment (12). Vincristine is a vinca alkaloid antimitotic agent able to block the formation of microtubules in cells (20). Toxicities associated with myelosuppression and neurotoxicity require relevant precautions. In particular, vincristine has been reported to cause loss of deep tendon reflexes, peripheral neuropathy and abdominal autonomic disturbance, such as constipation (21). The effects of angiography and embolization have been shown to be temporary and are used primarily as an adjunct to surgery, in order to minimize bleeding during a planned resection (22). In certain refractory cases, in which the patient cannot be tapered off of the corticosteroids, chemotherapy is used. Therefore, the most common chemotherapy used in such cases is cyclophosphamide, either alone or combined with agents such as vincristine and actinomycin-D (23). Propranolol is a non-selective $\beta$-adrenergic antagonist, widely used in the treatment of infantile hemangioma; KMP-associated tumors have been shown to have a variable response to propranolol, and therefore the optimal dose has not yet been established $(13,18)$. Sirolimus, a mammalian target of rapamycin inhibitor, was previously tested in a prospective clinical trial for complicated vascular anomalies (15). However, due to the refractoriness of the treatment, the study did not conclude the best way to deal with KMS.

In a previous study, no platelet antibodies or evidence of an anti-immune process were found to be responsible for the destruction of platelets, which suggests that their destruction may have been due to another mechanism (24). In the present case, however, a positivity of $63.08 \%$ for platelet antibodies was detected (normal value, $<30 \%$ ). Prothrombin time and activated partial thromboplastin time have been shown to be either normal or slightly elevated in KMS (16). There were no signs of bleeding and platelet transfusion may have been unnecessary in the present study.

The present study reports a case of KMS as a result of TA, which was managed with multimodal treatment. Although the present patient obtained an optimal objective long-term response with disease control, well-designed, large-scale studies are required in order to clearly determine the benefits and risks of multidisciplinary treatment for KMS. However, accumulating sufficient patients for such studies may be challenging.

\section{Acknowledgements}

The authors would like to thank Mr. Grahay Rester (Zhejiang Ivy International High School, Hangzhou, China) for reviewing the present manuscript.

\section{References}

1. Kasabach HH and Merritt KK: Capillary hemangioma with extensive purpura: report of a case. Am J Dis Child 59: 1063-1070, 1940.

2. Enjolras O, Mulliken JB, Wassef M, Frieden IJ, Rieu PN, Burrows PE, Salhi A, Léauté-Labreze C and Kozakewich HP: Residual lesions after Kasabach-Merritt phenomenon in 41 patients. J Am Acad Dermatol 42: 225-235, 2000.

3. Le Nouail P, Viseux V and Enjolras O; Groupe de Recherche Clinique en Dermatologie Pédiatrique: Kasabach-Merritt phenomenon. Ann Dermatol Venereol 134: 580-586, 2007 (In French).

4. O'Rafferty C, O'Regan GM, Irvine AD and Smith OP: Recent advances in the pathobiology and management of Kasabach-Merritt phenomenon. Br J Haematol 171: 38-51, 2015.

5. Ferrandiz-Pulido C, Mollet J, Sabado C, Ferrer B and Garcia-Patos V: Tufted angioma associated with Kasabach-Merritt phenomenon: A therapeutic challenge. Act Derm Venereol 90: 535-537, 2010

6. Chu CY, Hsiao $\mathrm{CH}$ and Chiu HC: Transformation between Kaposiform hemangioendothelioma and tufted angioma. Dermatology 206: 334-337, 2003.

7. Nakagawa K: Case report of angioblastoma of the skin. Jpn J Dermatol 59: 92-94, 1949.

8. Jones EW and Orkin M: Tufted angioma (angioblastoma). A benign progressive angioma, not to be confused with Kaposi's sarcoma or low-grade angiosarcoma. J Am Acad Dermatol 20: 214-225, 1989.

9. Sadeghpour M, Antaya RJ, Lazova R and Ko CJ: Dilated lymphatic vessels in tufted angioma: A potential source of diagnostic confusion. Am J Dermatopathol 34: 400-403, 2012.

10. Hall GW: Kasabach-Merritt syndrome: Pathogenesis and management. Br J Haematol 112: 851-862, 2001.

11. Kim T, Roh MR, Cho S and Chung KY: Kasabach-merritt syndrome arising from tufted angioma successfully treated with systemic corticosteroid. Ann Dermatol 22: 426-430, 2010.

12. Fahrtash F, McCahon E and Arbuckle S: Successful treatment of kaposiform hemangioendothelioma and tufted angioma with vincristine. J Pediatr Hematol Oncol 32: 506-510, 2010.

13. Hermans DJ, van Beynum IM, van der Vijver RJ, Kool LJ, de Blaauw I and van der Vleuten CJ: Kaposiform hemangioendothelioma with Kasabach-Merritt syndrome: A new indication for propranolol treatment. J Pediatr Hematol Oncol 33: e171-e173, 2011.

14. Mahendran R, White SI, Clark AH and Sheehan-Dare RA: Response of childhood tufted angioma to the pulsed-dye laser. J Am Acad Dermatol 47: 620-622, 2002.

15. Hammill AM, Wentzel M, Gupta A, Nelson S, Lucky A, Elluru R, Dasgupta R, Azizkhan RG and Adams DM: Sirolimus for the treatment of complicated vascular anomalies in children. Pediatr Blood Cancer 57: 1018-1024, 2011.

16. Rodriguez V, Lee A, Witman PM and Anderson PA: Kasabach-merritt phenomenon: Case series and retrospective review of the mayo clinic experience. J Pediatr Hematol Oncol 31: 522-526, 2009.

17. Wang Z, Li K, Dong K, Xiao X and Zheng S: Variable response to propranolol treatment of kaposiform hemangioendothelioma, tufted angioma and Kasabach-Merritt phenomenon. Pediatr Blood Cancer 61: 1518-1519, 2014.

18. Chiu YE, Drolet BA, Blei F, Carcao M, Fangusaro J, Kelly ME, Krol A, Lofgren S, Mancini AJ, Metry DW, et al: Variable response to propranolol treatment of kaposiform hemangioendothelioma, tufted angioma and Kasabach-Merritt phenomenon. Pediatric Blood Cancer 59: 934-938, 2012.

19. Choi JW, Na JI, Hong JS, Kwon SH, Byun SY, Cho KH, Youn SW, Choi HS, Park KD and Park KC: Intractable tufted angioma associated with kasabach-merritt syndrome. Ann Dermatol 25: 129-130, 2013.

20. Brunton L, Lazo J and Paker K (eds). Goodman \& Gliman's The Pharmacological Basis of Therapeutics. 11th edition. McGraw-Hill, New York, 2005. 
21. Haisley-Royster C, Enjolras O, Frieden IJ, Garzon M, Lee M, Oranje A, de Laat PC, Madern GC, Gonzalez F, Frangoul H, et al: Kasabach-merritt phenomenon: A retrospective study of treatment with vincristine. J Pediatr Hematol Oncol 24: 459-462, 2002.

22. Drolet BA, Trenor CC III, Brandão LR, Chiu YE, Chun RH, Dasgupta R, Garzon MC, Hammill AM, Johnson CM, Tlougan B, et al: Consensus-derived practice standards plan for complicated Kaposiform hemangioendothelioma. J Pediatr 163 285-291, 2013.
23. Hauer J, Graubner U, Konstantopoulous N, Schmidt S, Pfluger T and Schmid I: Effective treatment of kaposiform hemangioendotheliomas associated with Kasabach-Merritt phenomenon using four-drug regimen. Pediatr Blood Cancer 49: 852-854, 2007.

24. de la Hunt MN: Kasabach-Merritt syndrome: Dangers of interferon and successful treatment with pentoxifylline. J Pediatr Surg 41: e29-e31, 2006 